\title{
Reforming the financial system to insure the provision of health-resort services
}

\author{
Alla Baranova $^{1}$, and Svetlana Kegeyan ${ }^{1, *}$ \\ ${ }^{1}$ Sochi State University, Sovetskaya st., 26a, 354000, Sochi, Russia
}

\begin{abstract}
The purpose of health resort institutions' activity is the health improvement of the population and the maintenance of its viability. In recent years state support for the financing of health and resort packages of citizens has been declining, the prices for recreational services are growing. This article reveals the shortcomings of the hierarchical system of financial support for health resort institutions and presents the structure of combined financial support for health resort services.
\end{abstract}

\section{Introduction}

In accordance with the long-term socio-economic Concept development of the Russian Federation for the period until 2020 and the Concept development of the sanatorium and tourist complex of the Krasnodar Territory until 2030 one of the main directions of innovative development of the country's economy is the creation of conditions for improving the quality of life of the population, owing also to the development of leisure infrastructure, quality assurance, accessibility and competitiveness of domestic sanatoriumresort services $[1,2]$.

Health resort services are services provided by accommodation organizations with medical and preventive functions to holiday makers to meet their needs in health resort and treatment rest [3].

Financing and management of spa area in Russia belongs to the competence of various authorities: health-resort and boarding houses with treatment are under the jurisdiction of the Ministry of Health of the Russian Federation; educational establishments preparing personnel for the health-resort complex are under the jurisdiction of the Ministry of Education and Science of the Russian Federation; the development and implementation of priority investment projects of federal districts and special economic zones is carried out by the Ministry of Regional Development of the Russian Federation. Moreover, the Federal Tax Service and the Social Insurance Fund of the Russian Federation play an important role.

There is a state support for the provision of health-resort services in Russia, for example, funding the vouchers but this is not enough. It is necessary to promote the health resort institutions activity with the aim of attracting more recreants that will ensure their financial stability.

* Corresponding author: svetlana.kegeyan@mail.ru 


\section{Methods}

The methods of institutional and logical analysis, generalization and observation were the basis of the research. Statistical analysis and study of relevant legislative acts allowed to ensure the reliability of the conducted research and validity of the conclusions. In the field of health resort activity the works of the authors-specialists (AM Vetetnev, Drobyshevskaya LN, Salomatina EV, Sannikov AL, Sidorov AV) were studied and as a result the problems of health-resort services providing were revealed. The authors suggested measures of improving the provision of health-resort services in terms of management and marketing. This article presents the ways of problems solutions from the point of view of modernizing the financial provision of sanatorium and spa services.

\section{Results}

The financial security of any organization is determined by the set of financial resources and the nature of the partnership relationships. Financial resources are the whole complex of all types of monetary funds and financial assets that economic entities (state, organizations, entrepreneurs, population) have and use to maintain the desired proportions of functioning [4-7].

The main sources of financial resources are:

- own funds of organizations (profit, depreciation);

- borrowed funds (loans and borrowings);

- attracted resources (budgetary funds, investments, leasing, dividend fund, etc.) [4-7].

The financial system is the whole complex of various spheres of financial relations during which the funds of the state and organizations are formed, distributed and used [5, $8]$.

The traditional structure of the state financial system:

1. budgets of different levels of government;

2. off-budget funds;

3. state credit;

4. finances of organizations;

5. household finances.

Thus, financing of organizations in the health resort sector is characterized by hierarchical management of financial resources (Fig. 1).

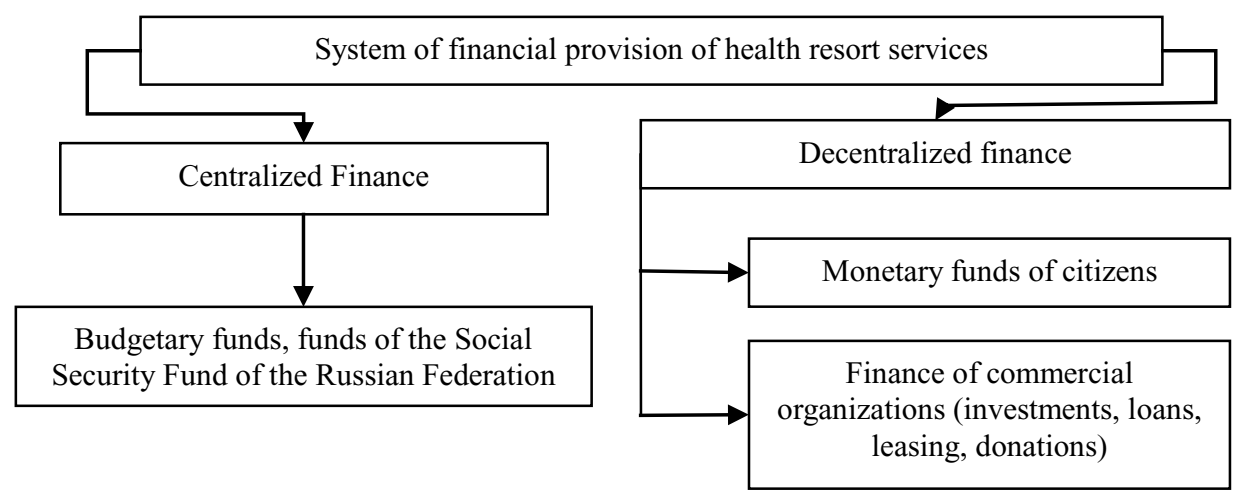

Fig. 1. Structure of the traditional system of financial provision of health resort services (hierarchical management system). 
At the federal level most of the funding is provided for territories within the framework of federal targeted programs, in part a number of sanatoria (boarding houses) at the expense of the funds of the Social Security Fund of the Russian Federation when granting vouchers of relevant ministries (departments)to citizens relevant and regulatory legal acts are being developed with the purpose of forming a favorable investment climate and an effective mechanism for taxation of recreational organizations and resorts.

At the regional level the management of the health resort area is more effective than its financing, requiring certification, creating associations of resort organizations implementing activities for promoting recreational products, etc.

The efforts of the municipal authorities are aimed at maintaining the infrastructure of the resort areas (bank protection works, protection of cultural and art monuments, landscaping, development of deposits of medical springs, etc.), as well as organizing and holding exhibitions, investment forums, major scientific and cultural events in the offseason with the purpose of ensuring the influx of tourists and recreants.

The Federal Tax Service of the Russian Federation performs the following main functions: monitoring compliance with the legislation on taxes and other mandatory payments to the budget, ensuring timely and full accounting of taxpayers and granting tax benefits.

The Social Insurance Fund of the Russian Federation fulfills the social function of the state by means of health-resort vouchers financing .

The Ministry of Regional Development of the Russian Federation coordinates the development and implementation of priority investment projects of federal districts and special economic zones, the functions of providing state support at the expense of the funds of the Investment Fund of the Russian Federation, subsidies from the federal budget, holding exhibitions and forums, acting as the ordering customer of works concerning plans for the creation and development of tourist-recreational and auto-tourism clusters, etc.

As a result of the interaction of market entities the following methods of financial provision of health resort services arise: leasing, outsourcing, lending, direct and portfolio investment.

The trend of providing sanatorium and health resort services is presented in Table. 1.

Table 1. The number of health resort organizations and the number of people served in Russia [9].

\begin{tabular}{|c|c|c|c|c|c|}
\hline $\begin{array}{c}\text { Types of } \\
\text { organizations }\end{array}$ & 1992 & 2000 & 2005 & 2010 & 2015 \\
\hline $\begin{array}{c}\text { Health-resort } \\
\text { organizations (HRO) } \\
\text { and recreation } \\
\text { organizations (units) }\end{array}$ & 6931 & 4876 & 4457 & 3886 & 3689 \\
\hline $\begin{array}{c}\text { Number of people } \\
\text { served in } \\
\text { HRO(thousand } \\
\text { people) }\end{array}$ & 13348 & 8873 & 10281 & 9709 & 10359 \\
\hline
\end{tabular}

According to statistical information on health resort organizations of the city-resort of Sochi, the vast majority of such organizations' expenses is on the payment of personnel (30\%) although the number of staff annually declines and the health center maintenance $(24 \%)$. Most of these types of expenditures are not covered by budgetary subsidies for vouchers [10]. It was revealed that on average the incomes of health-resort organizations are: from the sale of rooms $-6.2 \%$, from the sale of vouchers $-88 \%$, additional services $-5.8 \%$. In the section of additional services health-therapeutic services predominate $-47.4 \%$. It can be concluded that health services are in high demand but with the price rising and the quality of their delivery decreasing, the number of recreants is declining [10]. 
Modern health-resort organizations have financial difficulties due to a reduction in state funding and a reduction in the number of recreational days due to the high cost of services. Therefore, in the near future, organizations will function with an emphasis on leisure and recreational activities to the detriment of spa medicine, the dominant place of which has always been distinguished by domestic health resorts from the western ones where recreation is predominant at the base of resort recreation [11].

In the course of the theoretical research it was revealed that there are a number of reasons in the management of health-resort organizations that reduce profitability as a whole [12]:

1. work with incompatible target audiences;

2. decrease in the quality of service due to the reduction in the number of procedures;

3. focusing on low-efficiency channels of advertising and sales;

4. focus on the price component of competition, etc.

Health-resort houses with treatment are forced to provide innovative therapeutic developments that are not included in the cost of the voucher, at inflated prices for a fee in order to pay back the costs of innovation and investment. As a result, a person who has arrived on a tour receives a cheaper set of services, which generally reduce the quality of the rest if he does not take advantage of more advanced medical services for a fee.

Thus, the hierarchical system of financial provision of health-resort services needs modernization.

\section{Discussion}

In fact, a hierarchical system of financing and management which is a structure with a clear division of responsibilities between departments: budgeting, planning, project management, recruitment, control, management, financing is able to work effectively for many years [13]. But as a result of the variability of market conditions, the hierarchical system cannot be changed, it is not flexible and complex.

In a market environment a network management and financing system functions effectively which is a solar system, where the sun is a strategy, the planets are strategic initiatives, the satellites are projects. Such a system is typical for start-up companies (startups) which must be flexible, fast and creative [13].

Consider these two systems in relation to health-resort organizations. It should be concluded that the hierarchical system cannot be broken but it is possible to integrate the network system in it so that the combined financial security system would appear eventually (Figure 2 ).

At present the health resort institutions financing is based not only on government subsidies and the funds of the Social Insurance Fund of the Russian Federation, they have been working for a long time primarily on the basis of self-sufficiency and self-financing solving the problems of competitiveness, not only with price factors, but also with price factors, for example, expansion of the range.

Improving the entrepreneurial activity of organizations in the health resort sector, increasing the quality of services and increasing profitability depend on their ability:

- to study and forecast the demand for health-improving services from the side of the reentertainers and similar proposals of competitors;

- to provide innovative services;

- to find effective sources of financing for entrepreneurial activity.

Management of financial resources of any commercial organization includes the following tasks:

- optimization of own financial resources; 
- organization of financial relations with other organizations: banks, insurance companies, investors, etc. (for example, placement of capital, issue of shares and bonds, bank and commercial loans), etc.

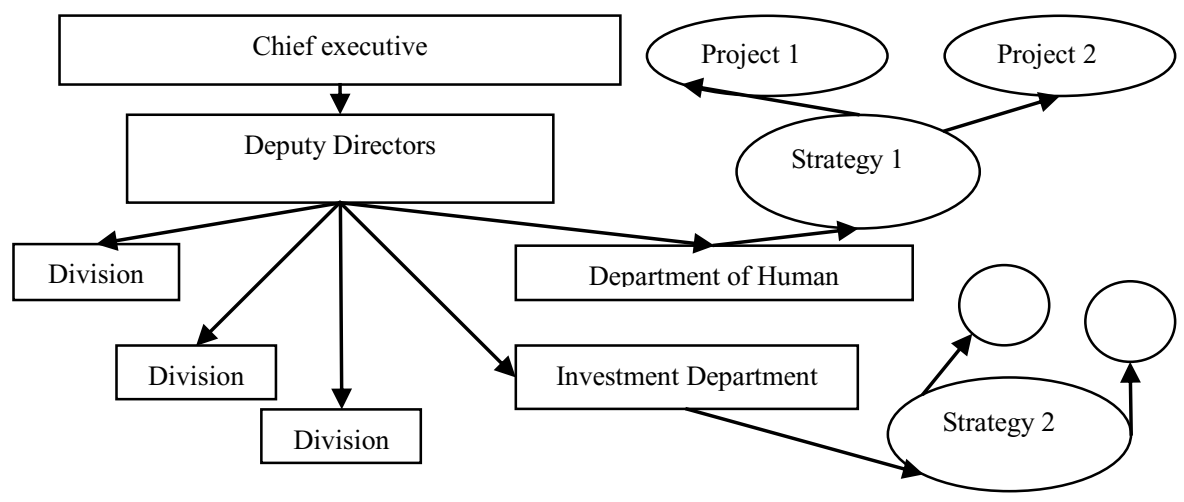

Fig. 2. Combined system of financing and management.

Since the financing of health resort services in Russia is planned to be reduced at the expense of public funds, and investors are interested in the highly profitable branches of Russian industry, then the money resources of the population and corporate organizations should be considered as sources of investment. In this matter our country is ready to adopt experience of Western Europe countries, in particular Spain, Germany, the Czech Republic, Hungary, where vacation vouchers have long functioned as a support for social tourism [14, p. 9].

The essence of holiday vouchers is that the enterprise will purchase tourist them directly at the health-resort at a market price and sell to its employees at a price of 30,50 or $70 \%$ of the total cost depending on the terms and conditions of their repayment. With the help of such a measure it is planned to increase the congestion of health resorts in the low season providing recreational services with a large discount, as a result of which the organization itself will receive benefits to pay income tax [15]. However, there is a risk of employees refusing to purchase these vouchers and then the acquiring organization will be at a loss.

Therefore, as a more effective method of investing in health resort services, it is suggested to attract monetary funds from the population and organizations by means of issuance of resort bonds. In accordance with the Law on Securities Market, a bond is a security that secures the right of its holder to receive income or other property equivalent from the issuer [16].

The owner of the bond has the right to receive income (a fixed percentage of its nominal value or when the bond is redeemed, previously sold at a discount). For issuing organizations the advantage of bonds, unlike shares, is to attract investments without increasing the number of owners and the possibility of paying out funds on the bond for a long period.

Unlike holiday vouchers, an organization will purchase resort bonds for its employees at health resorts with a discount rather than at a market price and pay them at face value. After the purchase they will be offered for sale among the employees with a discount of 30 to $70 \%$, depending on the set of included services and the rest period. In the event of a weak sale of bonds, the acquiring organization may apply to the health center for a specified period at the nominal value. Thus, a number of advantages are obtained for participants of this financing scheme:

1. health resorts receive borrowed resources with less encumbrance than bank loans; 
2. the organization-acquirer does not bear losses in connection with the sale of bonds, moreover, it has the right to tax privileges, which should be prescribed in Ch. 25 "Profit Tax" of the Tax Code of the Russian Federation. Such organization deserves a privilege along with legal entities participating in voluntary medical insurance;

3. the employees of the organization will receive recreational services at a reduced price, the set and the time of performance of which will be selected.

The development of the digital economy and IT technologies has been developing for a long time in Russia, which also needs to be used to provide health resort services. For example, the need for digital treatment of the medical history and the creation of remote medical consulting centers has appeared. And then health resorts can use such methods as outsourcing, outstaffing, development of client-oriented marketing.

The basis of the functioning of this model is as follows:

1. The Ministry of Health of the Russian Federation forms the Unified Database of Russian Health and Resort Organizations (HRO) describing their specialization and location. On a quarterly basis the responsible executives of the SRO submit to the Unified Database a list of well-known medical personnel (full time staff and invited) who will provide services of the appropriate profile indicating the period of their work;

2. polyclinics, hospitals, medical higher and secondary institutions that train the relevant personnel, send their employees and students on a business trip (for practice) to a specialized health-resort organizations with treatment at a certain time in consultation with the management of the HRO.

3. it is possible to reduce the number of staff medical personnel in the HRO which will be replenished by invitations on the basis of an agreement between the employee and the head of the HRO performing payroll;

4. consumers of recreational services and polyclinics can use the Single base of the HRO as information;

5. the partner organizations send their employees on a permanent or single basis to the corresponding health-resort organizations.

The suggested recommendations will contribute to providing quality services to reentertainments by attracting qualified medical personnel, exchanging experience between employees, reducing labor costs with a possible reduction in staff and growing health center revenues by increasing the number of people ready to use the services of well-known doctors.

\section{Conclusions}

With the purpose of effective development of health resort services a combined system of financing and management is needed, which includes hierarchical and network systems. Hierarchical system of financing is a long-established system of attracting and using financial resources (own profit, depreciation, state monetary funds), which cannot be broken. At present recreants need to get affordable innovative services. For this purpose it is necessary for the management of health resorts to activate the network financing system using outsourcing, outstaffing, the development of client-oriented marketing, the securities market.

\section{References}

1. Kontseptsiya dolgosrochnogo sotsial'no-ekonomicheskogo razvitiya Rossiyskoy Federatsii na period do 2020 goda (Pravitel'stvo RF, 2008) 
2. URL : https://min.kurortkuban.ru/dokumenty/normativnye-akty/kontseptsiya-razvitiyasanatorno-kurortnogo-i-turistskogo-kompleksa-krasnodarskogo-kraya-do-2030-god/

3. A.M. Vetitnev, Ya.A.Voynova, Organizatsiya sanatorno-kurortnoy deyatel'nosti, uchebnoe posobie (Federal'noe agentstvo po turizmu, Moscow, 2014)

4. V.V. Bocharov, V.E. Leont'yev, N.P. Radkovskaya, Finansy (Piter, SPb, 2009)

5. V.K. Senchagov, A.I. Arkhipov, Finansy, denezhnoe obrashchenie, kredit (TK Velbi, Prospekt, Moscow, 2010)

6. G.B. Polyak, Gosudarstvennye i munitsipal'nye finansy (YuNITI-DANA, Moscow, 2012)

7. T.V. Kirichenko, Finansovyy menedzhment (Dashkov i K, Moscow, 2013)

8. V.V. Kovalev, Finansy (Prospekt, Moscow, 2014)

9. URL :http://www.gks.ru/wps/wcm/connect/rosstat_main /rosstat/ru/statistics/publications/catalog/doc_1135075100641

10. A.Yu. Baranova, Ekonomika i predprinimatel'stvo 7, 759-766 (2016)

11. A.L. Sannikov, A.V. Sidorov, Sovremennye problemy nauki i obrazovaniya, 2-1 (2015) http://www.science-education.ru/ru/article/view?id=19164

12. L.N. Drobyshevskaya, E.V. Salomatina, Fundamental'nye issledovaniya 7-2, 382-386 (2015)

13. Zh.P. Kotter, Uskorenie peremen (ZAO «Olimp-Biznes», Moscow, 2014)

14. URL : http://cyberleninka.ru/article/n/sotsialnyy-turizm-v-rossii-i-v-evrope

15. Rosturizm vvedet otpusknye cheki, http://therussiantimes.com/news/5588.html

16. Federal'nyy zakon «O rynke tsennykh bumag» ot 22.04.1996 g. № 39-FZ 